\title{
A new species of Trox from the Amazon Basin with new distributional records for Central American Trox (Coleoptera: Scarabaeidae)
}

\author{
Brett C. Ratcliffe (")
}

\begin{abstract}
Trox juglans is described as new from the Amazon Basin in Brazil, and new distribution records are given for Trox fulginosus Robinson, T. loxus Vaurie, T. punctatus Germar, T. tomentosus Robinson, and T. variolatus Melsheimer.
\end{abstract}

Only two species of Trox (T. suberosus (Fabr.) and $T$. batesi Harold) are known to occur in the forests of Brazil's Amazon Basin. Trox spp. are not well established there possibly because the continual, very humid forest conditions are not suitable or because they have been out-competed in their ecological role in these humid forests by other animals such as ants, for example. The specimens described as new here were taken at INPA's Reserva Ducke, near Manaus, in an area of tropical humid forest (terra firme; primary forest) and were collected by using baited pitfall traps. The bait for these traps consisted of a small amount of fish suspended above either a $5 \%$ chloral hydrate solution or a $25 \%$ picric acid solution. Eight specimens were taken with the two combinations over a nine month period in a system using ten traps spaced 50 meters apart and collected week!y. This same area was also sampled with black light traps, but Trox sp. were not taken.

\section{Trox juglans, new species} (Figs. 1-4)

TYPE MATERIAL - Holotype male, labeled "BRASIL: Amazonas, Reserva Ducke, 26 km NE Manaus, IX-27-1977, B. C. Ratcliffe." Allotype female with same data as holotype. Four male and two female paratypes with same locality data but with dates of XI-1-1977, I-3-1978, I-17-1978, ||-14-1978, and V-2-1978. Types" deposited at the Instituto Nacional de
Pesquisas da Amazônia (INPA). Paratypes deposited at the Museu de Zoologia da Universidade de São Paulo (MZSP), in the Brett C. Ratcliffe collection (BCRC), and at the American Museum of Natural History (AMNH).

HOLOTYPE - Male. Length $8.0 \mathrm{~mm}$; greatest width $4.5 \mathrm{~mm}$. Color light brown. Head: Frons bituberculate. Clypeus with apex triangular, deflexed, anterior edge distinctly emarginate in dorsal view. Scape of antenna piceous with fulvous hairs; club ferruginotestaceous. Pronotum (Figs. 1-2) : Length width ratio $3: 4$. Base drawn backward in obtuse lobe. Sides bulbous in front of middle, strongly emarginate in front of basal angle, basal angle acutely lobed; margin with small, sparse hairs. Center of pronotum with 2 strongly elevated, longitudinal ridges; ridges extend from apex to base, constricted mesad just below middle; ridges at mesal constriction appear subtuberculate in dorsal view; a shallow

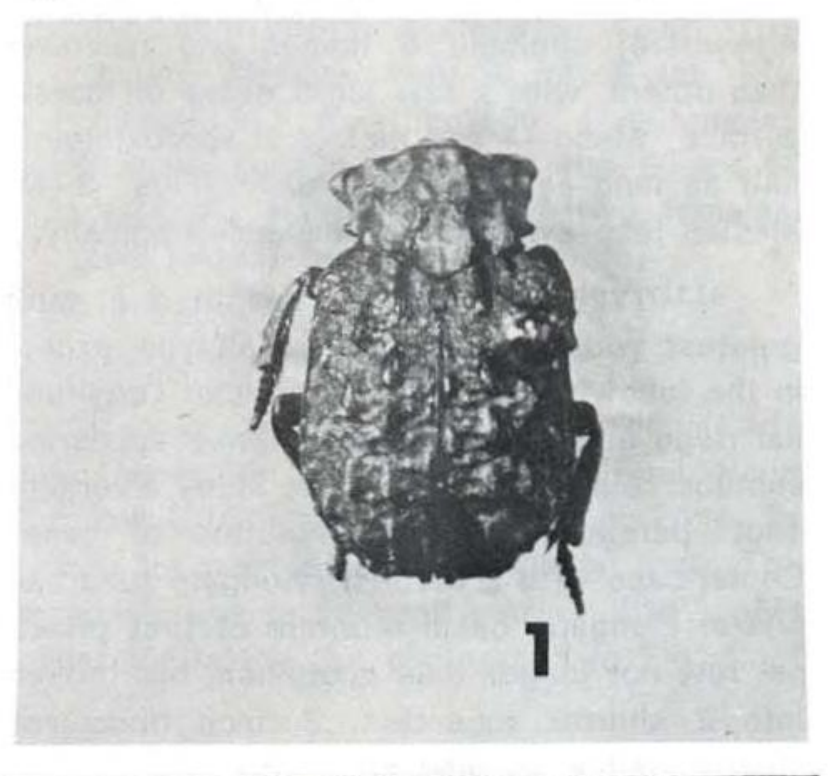

Fig. 1 - Trox juglans, dorsal view.

(•) - Instituto Nacional de Pesquisas da Amazônia, Manaus. 
fovea on each ridge just anterior of mesal constriction. Surface moderately punctate; punctures small, shallow, non-setigerous. Scutellum (Fig. 2): Scutellum about twice as long as wide, sides slightly convergent to middle, divergent to apical third quarter, then convergent to apex. Elytra: Each elytron with 4 rows of 4-6 tubercles from base to subapical declivity, first 2 rows on disc, last 2 rows across and behind humerus and on side below humerus; tubercles bulbous, elevated, impunctate, round in smaller tubercles, elongate in larger tubercles, tomentose on top; basal tubercle in first principal row longer than scutellum; tubercles large in discal and post-humeral rows, smaller in side row. Intervals between principal rows with small tubercles; suture and marginal interval with tubercles subequal in size to those of 4 th principal row. Humeral callus large, bulging. Lateral margin with sparse, very small setae. Surface with punctures obscured on disc due to coating, visible laterally; punctures moderate in density, large, moderately deep. Legs: Outer edge of tibia smooth, a few short setae present. Tarsal segments 1-4 on second and third pairs of legs smooth (not ridged), subequal, about as long as wide; apex of each with several setae, setae ventrally nearly as long as segment, half as long as segment elsewhere; segment 5 longer and narrower than others, with a few short setae on dorsal surface. Meso - and metatarsi approximately half as long as tibia. Genitalia (Figs. 3-4): Median lobe symmetrical, expanded apically.

ALLOTYPE - Female. Length $9.5 \mathrm{~mm}$; greatest width $6.0 \mathrm{~mm}$. As holotype except in the following respects: Pronotum: Longitudinal ridge at mesal constriction not appearing subtuberculate in dorsal view; sides divergent (not parallel) from constriction to base. Center-base with a distinct, elongate tubercle. Elytra: Elongate, basal tubercle of first principal row not longer than scutellum, but broken into 2 shorter tubercles. Surface punctures clearly visible on disc and sides.

VARIATION - Males (4 paratypes): Length 8.5-9.0 mm; greatest width $5.0-5.5 \mathrm{~mm}$. Pronotum: Longitudinal ridges with basal part subparallel, then slightly convergent at base. Elytra: Elongate, basal tubercle of first principal row entire to divided into 2 shorter tubercles. Disc and sides with punctures partially obscured to clearly visible; punctures moderate in density, large, moderately deep.

Females (2 paratypes): Length $9.0 \mathrm{~mm}$; greatest width $5.2-5.5 \mathrm{~mm}$. Pronotum: Longitudinal ridges with basal part slightly to distinctly convergent at base. Elytra: Elongate, basal tubercle of first principal row entire to divided into 2 shorter tubercles. Punctures partially obscured by coating.

DISCUSSION - Trox juglans is included in Vaurie's (1962) brevicollis group of South American Trox because of the deflexed clypeal apex, large and bulbous eyes, long wings, and form of the genitalia. It most closely re-
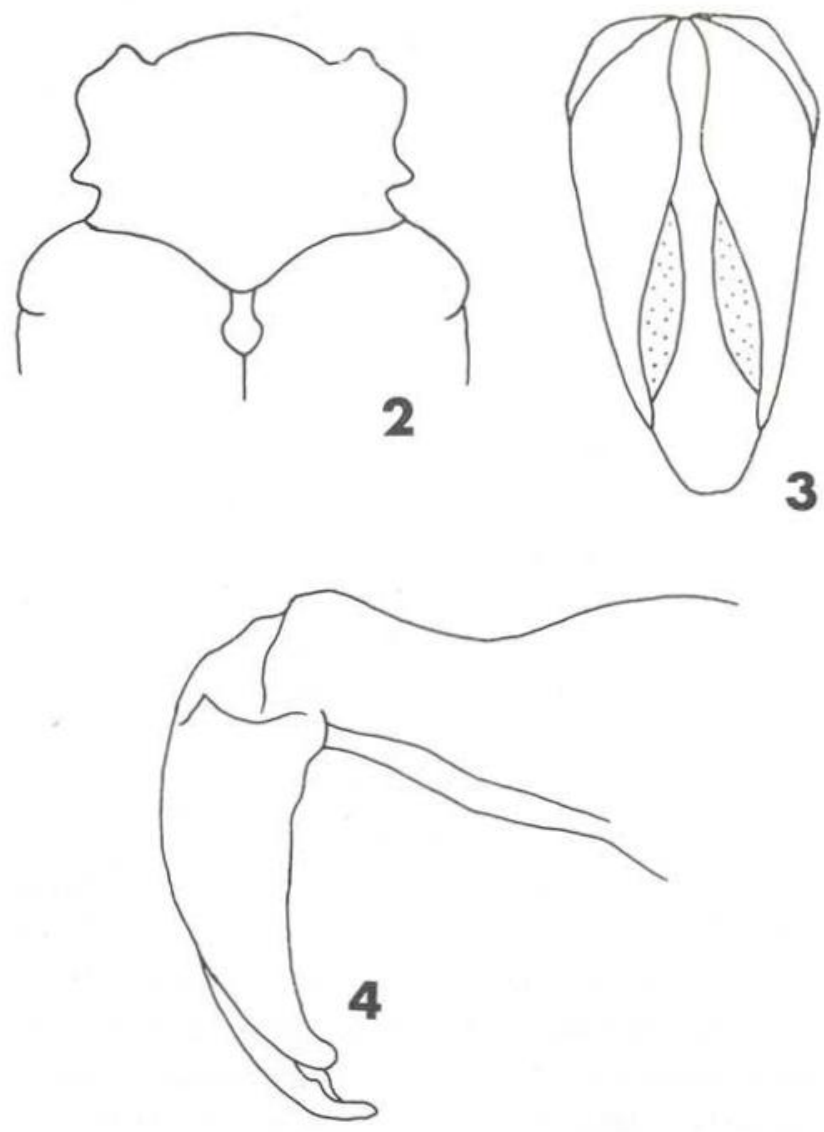

Fig. 2 - T. juglans. Form of pronotum and scutellum; Fig. 3-4 $-\mathbf{T}$. juglans. Lateral and caudal views of male genitalia. 
sembles Trox bifurcatus Vaurie and, except for the genitalic character, will key to $T$. bifurcatus in Vaurie's revision of the South American species. However, T. bifurcatus possesses genitalia with a very distinctive, forked median lobe whereas $T$. juglans has genitalia with the median lobe entire and expanded apically. much like those of $T$. brevicollis Eschscholtz. Trox brevicollis is unlike $T$. juglans in that it has black antennal hairs, a differently shaped pronotum and scutellum, and longer hind tibiae. Although all three of the above species are found in Brazil, $T$. juglans is the only species to be found in the Amazon Basin.

ETYMOLOGY - The color and moulding of the dorsal surface of this species are reminiscent of a walnut, Juglans regia, hence the appelation Trox juglans.

\section{NEW DISTRIBUTION RECORDS}

The following records are new for Mexico and Central America; these records supplement the data accumulated by Vaurie (1955, 1958, 1962). Collection abbreviations given below are those of Arnett \& Samuelson (1969).

Trox fulginosus Robinson. Mexico: “Jalisco, $11.5 \mathrm{mi}$ NW Barra de Navidad, 14-IX-71 A. Newton" (1 male, 1 female); "San Luis Potosi, $3 \mathrm{mi}$. W El Naranjo, 10-18-VI-71, A. Newton, 1100'" (one male) (new state records). El Salvador. "20 km E La Libertad, 3-V-71, H. F. Howden" (four males, two females); "3 km S Santa Tecla, 11-V-71, H. F. Howden" (one female) (new country records). Costa Ríca: "Guanacaste, Finca Pacifica, Canas, 17-VII-66, S. Peck, carrion" (two males, two females) (new country record). All above in HAHC.

Trox loxus Vaurie. Panamá: “Dist. Chepo, Altos de Majé, 17-V-75, Stockwell-Engleman, at lights" (three males, three females) (Stockwell collection, BCRC, HAHC); "Majé, $9^{\circ} 10^{\prime} \mathrm{N}, 70^{\circ} 45^{\prime} \mathrm{W}, 18-\mathrm{V}-74$, Engleman, light trap" (one female) (HAHC) (new country records). Vaurie (1962) suggested, based on material from southern Brazil and Argentina, that Trox loxus is a truly South American species, and that the single female specimen (holotype) from Mexico was probably "carried to the port of Veracruz by chance". While this may be the case, I believe the new Panamanian records indicate more of a continuum in the distribution than was previously known and, therefore, makes plausible the possibility of an established population in Mexico. In view of this further data, I would now discount Vaurie's explanation for the previously known Mexican record. Trox loxus may occur in other areas of Central America but, like Trox juglans, is rare and not commonly encountered.

Trox punctatus Germar. Mexico: "Coahuila, Rte. 57, $66.8 \mathrm{~km}$ S Sabinas, VII-26-75, G. E. Ball \& H. E. Frania, U. V." (two females) (HAHC) (new state record).

Trox tomentosus Robinson. Mexico: "Jalisco, $26 \mathrm{mi}$. NW Barra de Navidad, IX-13-71, A Newton, 300'" (one male, one female) (HAHC, BCRC) (new state record).

Trox variolatus Melsheimer. Mexico: "Durango, $4 \mathrm{mi}$. W El Salto, 15-17-VI-71, S. Peck, 9000" " (one male); "Hidalgo, $4 \mathrm{mi}$. W Tulancingo, VIII-71, A. Newton, 7600'" (one male); "Nuevo Leon, $16 \mathrm{mi}$. S Jct. Rts. 60 and 68, A. Newton, 7600'" (one female); "Nuevo Leon, $18 \mathrm{mi}$. S Jct. Rts. 60 and 68, V-71, A. Newton, 8000'" (two females) (all $\mathrm{HAHC}$ ) (new state records).

\section{ACKNOWLEDGEMENTS}

I am grateful to Henry F. Howden (Carleton University, Ottawa, Canada, and Henry Stockwell (Gorgas Hospital, Canal Zone, Panamá) for permitting me to study their Trox material, and to Jorge R. Arias (INPA, Manaus) for taking the photograph in Fig. 1.

\section{Resumo}

E descrita uma nova espécie de Troginae - Trox juglans (Coleoptera: Scarabaeidae) da Bacia Amazonla brasileira. Foram encontradas novas localidades de 
distribuição para as espécies Trox fulginosus Robinson, T. loxus Vaurie, T. punctatus Germar, T. tomentosus Robinson, e T. variolatus Melsheimer.

\section{LITERATURE CITED}

Arnett, Jr., Ross H. \& Samuelson, G. A. (eds.)

1969 - Directory of Coleoptera Collections of North America (Canada through Panama). Dept. Ent., Purdue Univ., Lafayete, 123 p.
VAURIE, PATRICIA

1955 - A revision of the genus Trox in North America (Coleoptera, Scarabaeidae). Bull. American Mus. Nat. Hist. 106 (1) : 1-89.

1958 - New distribution records of North American Trox (Coleoptera, Scarabaeidae). Coleop. Bull. 12 : 43-46.

1962 - A revision of the genus Trox in South America (Coleoptera, Scarabaeidae). Bull. American Mus. Nat. Hist. 124 (4) : 101-168.

(Aceito para publicação em 08/05/78) 